\section{Effects of Nutrient Solution Management and Environment on Tomato in Small-scale Hydroponics}

\author{
Elisa Solis-Toapanta ${ }^{1}$, Paul R. Fisher ${ }^{1}$, and Celina Gómez ${ }^{1}$
}

ADDITIONAL INDEX wORDs. CEA, indoor gardening, nutrient uptake, pick-and-eat, urban agriculture

SUMMARY. Interest in hydroponic home gardening has increased in recent years. However, research is lacking on minimum inputs required to consistently produce fresh produce using small-scale hydroponic systems for noncommercial purposes. Our objectives were to 1 ) evaluate the effect of biweekly nutrient solution replacements $(\mathrm{W})$ vs. biweekly fertilizer addition without a nutrient solution replacement $(\mathrm{W} / \mathrm{O})$ on final growth, yield, and nutrient uptake of hydroponic tomato (Solanum lycopersicum) plants grown in a greenhouse, and 2) characterize growth over time in a greenhouse or an indoor environment using W. For each environment, 'Bush Goliath' tomato plants were grown for 12 weeks in 6.5-gal hydroponic systems. The experiment was replicated twice over time. In the greenhouse, plants were exposed to the following day/night temperature, relative humidity $(\mathrm{RH})$, and daily light integral $(\mathrm{DLI})$ in 2018 (mean $\pm \mathrm{SD}): 31 \pm 6 / 22 \pm 2{ }^{\circ} \mathrm{C}, 67 \% \pm 8 \%$, and $32.4 \pm 7 \mathrm{~mol} \cdot \mathrm{m}^{-2} \cdot \mathrm{d}^{-1}$; and in 2019: $28 \pm 6 / 22 \pm 3{ }^{\circ} \mathrm{C}, 68 \% \pm 5 \%$, and $27.7 \pm 6$ $\mathrm{mol} \cdot \mathrm{m}^{-2} \cdot \mathrm{d}^{-1}$. For both experimental runs indoors, the day/night temperature, $\mathrm{RH}$, and DLI were $21 \pm 2{ }^{\circ} \mathrm{C}, 60 \% \pm 4 \%$, and $20 \pm 2 \mathrm{~mol} \cdot \mathrm{m}^{-2} \cdot \mathrm{d}^{-1}$ provided by broadband white light-emitting diode lamps. The $\mathrm{W} / \mathrm{O}$ treatment resulted in a higher-thandesired electrical conductivity (EC) and total nutrient concentration by the end of the experiment. In addition, compared with the $\mathrm{W}$ treatment, $\mathrm{W} / \mathrm{O}$ resulted in less leaf area, more shoot growth, less water uptake, and similar fruit number-but increased blossom-end-rot incidence, delayed fruit ripening, and lower fruit fresh weight. Nonetheless, the final concentration of all nutrients was almost completely depleted at week 12 under W, suggesting that the applied fertilizer concentration could be increased as fruiting occurs. Surprisingly, shoot biomass, leaf area, and leaf number followed a linear trend over time in both environments. Nonetheless, given the higher DLI and temperature, greenhouse-grown plants produced 4 to $5 \mathrm{~kg}$ more of fruit than those grown indoors, but fruit from plants grown indoors were unaffected by blossom-end-rot. Our findings indicate that recommendations for nutrient solution management strategies should consider specific crop needs, growing environments, and production goals by home gardeners.

$\mathrm{H}$ ydroponic home gardening of edibles is an expanding market segment, with multiple plug-and-play growing systems

Received for publication l July 2020. Accepted for publication 15 Sept. 2020

Published online 14 October 2020.

${ }^{1}$ Environmental Horticulture Department, University of Florida, Institute of Food and Agricultural Sciences, 1549 Fifield Hall, Gainesville, FL 32611-0670 Financial support was received from the U.S. Department of Agriculture, National Institute of Food and Agriculture, Multistate Research Project NE1835: Resource Optimization in Controlled Environment Agriculture. We thank the USDA, Agricultural Research Service, Floriculture and Nursery Research Initiative \#58-3607-8-725, the Scotts Co. and industry partners of the Floriculture Research Alliance at the University of Florida (floriculturealliance. org) for supporting this research.

C.G. is the corresponding author. E-mail: cgomezv@ ufl.edu.

This is an open access article distributed under the CC BY-NC-ND license (https://creativecommons.org/ licenses/by-nc-nd $/ 4.0 /$ ).

https://doi.org/10.21273/HORTTECH04685-20 available to consumers. Although gardening provides opportunities to connect urban dwellers with horticulture, most research-based information about hydroponic plant production supports commercial-scale cultivation, which aims to maximize profitability by maintaining high yields and limiting inputs.
In contrast, home gardeners who may use hydroponic systems have diverse motivations that center on the appreciation of growing plants, affordable access to fresh produce, and perceived health benefits, among others (Kirkpatrick and Davison, 2018). Interest in home gardening has increased in recent years as individuals seek to improve emotional well-being (Ambrose et al., 2020). Nonetheless, research is lacking on minimum inputs required to consistently produce fresh produce using small-scale hydroponic systems for noncommercial purposes.

Tomato (Solanum lycopersicum) is the most popular fruiting vegetable among home gardeners, in addition to being a crop of great economic and scientific importance (Heuvelink, 2018; Jones, 2008). While popular, environmental and management requirements make tomato production challenging for novice hydroponic gardeners (Resh, 2015). For example, tomato requires a considerably higher daily light integral (DLI) than most leafy greens and herbs, making production challenging under typical indoor light levels and depending on the season and location, in some outdoor patios or backyards (Dorais et al., 2017; Halleck, 2018). Additionally, plant nutrition plays a significant role in yield and productivity of tomato, and physiological disorders related to nutrient imbalances, such as blossom-end-rot (BER), are not uncommon in hydroponics (Heuvelink, 2018; Nederhoff, 1999; Peet, 2009). To ensure maximum yields and high-quality fruit, commercial growers typically adjust the nutrient solution depending on environmental conditions and plant developmental stages, using inline automated monitoring and control of solution $\mathrm{pH}$ and nutrient concentration. However,

\begin{tabular}{llll}
\hline $\begin{array}{l}\text { Units } \\
\begin{array}{l}\text { To convert U.S. to SI, } \\
\text { multiply by }\end{array}\end{array}$ & U.S. unit & SI unit & $\begin{array}{l}\text { To convert SI to U.S., } \\
\text { multiply by }\end{array}$ \\
\hline 29.5735 & $\mathrm{fl} \mathrm{oz}$ & $\mathrm{mL}$ & 0.0338 \\
0.3048 & $\mathrm{ft}$ & $\mathrm{m}$ & 3.2808 \\
3.7854 & gal & $\mathrm{L}$ & 0.2642 \\
2.54 & inch $(\mathrm{es})$ & $\mathrm{cm}$ & 0.3937 \\
25.4 & inch $(\mathrm{es})$ & $\mathrm{mm}$ & 0.0394 \\
6.4516 & inch & $\mathrm{cm}^{2}$ & 0.1550 \\
0.4536 & $\mathrm{lb}$ & $\mathrm{kg}$ & 2.2046 \\
1 & $\mathrm{mmho} / \mathrm{cm}$ & $\mathrm{dS} \cdot \mathrm{m}^{-1}$ & 1 \\
28.3495 & $\mathrm{oz}$ & $\mathrm{g}$ & 0.0353 \\
1 & $\mathrm{ppm}$ & $\mathrm{mg} \cdot \mathrm{kg}^{-1}$ & 1 \\
1 & $\mathrm{ppm}$ & $\mathrm{mg} \cdot \mathrm{L}^{-1}$ & 1 \\
$\left({ }^{\circ} \mathrm{F}-32\right) \div 1.8$ & ${ }^{\circ} \mathrm{F}$ & ${ }^{\circ} \mathrm{C}$ & $\left({ }^{\circ} \mathrm{C} \times 1.8\right)+32$
\end{tabular}

Hortlechnology · December 2020 30(6) 
adjusting the solution may be a daunting task for home gardeners, who at times struggle with interpreting nutrient solution formulation and management strategies (Jacoby, 1995).

In an analysis of social media posts, Solis-Toapanta et al. (2020a) found that nutrient solution management is the third most common topic searched among active online community subscribers interested in indoor gardening with hydroponics. In commercial and research hydroponic systems, maintaining a balanced nutrient solution typically requires periodic water refills, fertilizer replenishments, or complete nutrient solution replacements (Bugbee, 2004; Christie, 2014; Resh, 2015). In contrast, different management strategies could be used to minimize time, waste, and effort by home gardeners. In a study characterizing growth and nutrient uptake of hydroponically grown basil (Ocimum basilicum) in a greenhouse or indoors under solesource lighting, Solis-Toapanta et al. (2020b) showed that within each environment, plants could be grown successfully for 8 weeks without a nutrient solution replacement. However, due to the limited plant growth indoors, excess nutrients accumulated in the solution when it was not consistently replaced. The authors concluded that the limited growth rate of indoor-grown plants warrants reduced fertilizer input compared with the recommended approaches for water and nutrient management in a greenhouse.

To provide information that would facilitate nutrient management of small-scale hydroponics, our specific objectives were to 1) compare final growth, yield, and nutrient uptake of hydroponic tomato plants grown with either biweekly nutrient solution replacements or biweekly fertilizer additions without solution replacement in a greenhouse for 12 weeks, and 2) characterize growth over time in a greenhouse or indoor environment using a biweekly nutrient solution replacement for 12 weeks. We hypothesized that plant growth and yield would be higher with a regular solution replacement interval because nutrient concentration in the solution would approximate ideal levels immediately after solution replacement. In contrast, unused nutrients and other ions would accumulate in the reservoir of plants grown without a solution replacement. In addition, we hypothesized that plants grown indoors would be smaller, yield less, and have a lower nutrient uptake compared with those grown in a greenhouse because of lower indoor DLI and temperature.

\section{Materials and methods}

Plant material and growing conditions. Seeds of 'Bush Goliath' tomato (Totally Tomatoes Co., Randolph, WI) (determinate, beefsteak) were sown into 50 -cell trays $(34-\mathrm{mL}$ individual cell volume) of stabilized peatmoss plugs (Black Magic Starter Tray; Hawthorne Hydroponics, Las Vegas, NV) on 16 Jan. 2018 and 16 Jan. 2019 for the greenhouse environment and on 2 Aug. 2018 and 16 Jan. 2019 for the indoor environment. Seeds were germinated in an air-conditioned growth room at a constant temperature of $23{ }^{\circ} \mathrm{C}$ and $80 \%$ relative humidity (RH), where broadband white light-emitting diode (LED) lamps (RAY66 PhysioSpec Indoor; Fluence Bioengineering, Austin, TX) provided a photosynthetic photon flux density $(P P F D)$ of $100 \mu \mathrm{mol} \cdot \mathrm{m}^{-2} \cdot \mathrm{s}^{-1}$ for $16 \mathrm{~h} \cdot \mathrm{d}^{-1}$, resulting in a DLI of 5.8 $\mathrm{mol} \cdot \mathrm{m}^{-2} \cdot \mathrm{d}^{-1}$. Until germination occurred, seedlings were irrigated as needed with tap water with a 0.4 $\mathrm{dS} \cdot \mathrm{m}^{-1} \mathrm{EC}, 8.3 \mathrm{pH}$, and $31.2 \mathrm{mg} \cdot \mathrm{L}^{-1}$ calcium carbonate $\left(\mathrm{CaCO}_{3}\right)$, and containing (in $\mathrm{mg} \cdot \mathrm{L}^{-1}$ ) 0.3 nitrogen $(\mathrm{N})$ [combining 0.2 ammonium $\left(\mathrm{NH}_{4}-\mathrm{N}\right)$ and 0.1 nitrate $\left.\left(\mathrm{NO}_{3}-\mathrm{N}\right)\right], 0.1$ phosphorus $(\mathrm{P}), 1.7$ potassium $(\mathrm{K}), 36.8$ calcium (Ca), 23.4 magnesium $(\mathrm{Mg})$, 41.6 sulfur $(S), 0.02$ iron $(\mathrm{Fe}), 0.0$ manganese $(\mathrm{Mn}), 0.0$ zinc $(\mathrm{Zn})$, 0.0 copper $(\mathrm{Cu}), 0.03$ boron $(\mathrm{B}), 0.0$ molybdenum (Mo), 11.5 sodium $(\mathrm{Na})$, and 27.3 chloride $(\mathrm{Cl})$. After germination and before treatments were applied, plants were fertilized every $2 \mathrm{~d}$ with a dilute nutrient solution of $4 \mathrm{~N}-0 \mathrm{P}-0.8 \mathrm{~K}$ plus $2 \mathrm{~N}-1.3 \mathrm{P}-$ 5.8K (Root Farm Nutrients, Hawthorne Hydroponics). Concentration of the fertilizer was (in $\mathrm{mg} \cdot \mathrm{L}^{-1}$ ) $115.2 \mathrm{~N}$ (combining $19.2 \mathrm{NH}_{4}-\mathrm{N}$ and 96 $\left.\mathrm{NO}_{3}-\mathrm{N}\right), 22.5 \mathrm{P}, 126.6 \mathrm{~K}, 76 \mathrm{Ca}$, $28.2 \mathrm{Mg}, 32.2 \mathrm{~S}, 2.8 \mathrm{Fe}, 0.3 \mathrm{Mn}, 0.2$ $\mathrm{Zn}, 0.08 \mathrm{Cu}, 0.19 \mathrm{~B}, 0.01 \mathrm{Mo}, 3.8$ $\mathrm{Na}$, and $33.7 \mathrm{Cl}$.

At $22 \mathrm{~d}$ after sowing, uniform seedlings were selected, and each experimental run was initiated. One seedling was transplanted into the center opening of a single replicate deep-water culture hydroponic system $[40 \mathrm{~cm}$ height $\times 25 \mathrm{~cm}$ radius (Black Magic Grow Pail, Hawthorne Hydroponics)] using 2-inch-diameter net cups. Each 6.5-gal hydroponic system was black with an integrated pump at the bottom of the reservoir, which aerated the nutrient solution. Galvanized steel cages ( $4 \mathrm{ft}$ tall) were used to provide physical support for the plants.

Experimental Design AND $S$ O L U T I O N M A N A G E M E T T TREATMENTS. Plants were grown in either a greenhouse located in Gainesville, FL (lat. $29.6^{\circ} \mathrm{N}$, long. $82.3^{\circ} \mathrm{W}$ ) ("greenhouse environment") or in an air-conditioned indoor growth room ("indoor environment"), with two experimental runs per environment in 2018 and 2019. There were two treatments representing different nutrient solution management strategies for the greenhouse environment. In the first treatment, the nutrient solution was completely replaced every 2 weeks (W), and nutrients were allowed to deplete over time between biweekly replacement intervals. In the second treatment, the nutrient solution was not replaced, but the same amount of fertilizer as in the $\mathrm{W}$ treatment was added to the existing solution every 2 weeks $(\mathrm{W} / \mathrm{O})$. Because of space limitations, only the $W$ treatment was used in the indoor environment to characterize growth over time, which was selected based on data collected after the first experimental run in the greenhouse environment. Each experimental unit was a replicate hydroponic system with one tomato plant.

FerTiluzation. The water-soluble fertilizer added every 2 weeks had a $10 \mathrm{~N}-3.4 \mathrm{P}-13.3 \mathrm{~K}$ formulation (Scotts Co., Marysville, OH). Concentration of the fertilizer was (in $\mathrm{mg} \cdot \mathrm{L}^{-1}$ ) $178.3 \mathrm{~N}$ (from $15.7 \mathrm{NH}_{4^{-}}$ $\mathrm{N}$ and $\left.162.6 \mathrm{NO}_{3}-\mathrm{N}\right), 45.1 \mathrm{P}, 253.2$ $\mathrm{K}, 152.0 \mathrm{Ca}, 56.4 \mathrm{Mg}, 64.4 \mathrm{~S}, 2.1 \mathrm{Fe}$, $0.6 \mathrm{Mn}, 0.3 \mathrm{Zn}, 0.2 \mathrm{Cu}, 0.4 \mathrm{~B}, 0.03$ Mo, $7.7 \mathrm{Na}$, and $67.5 \mathrm{Cl}$, plus the additional ions in tap water. The $\mathrm{pH}$ was adjusted with an acid or a base ( $\mathrm{pH}$ Down or $\mathrm{pH}$ Up; General Hydroponics, Sebastopol, CA) to $\mathbf{5 . 5}$ to 6.5 immediately after adding fertilizer, which added either phosphoric and citric acid; or potassium carbonate and potassium silicate, 
respectively. Water level was monitored daily, and systems were refilled with tap water (refill water) whenever the solution dropped to $3 / 4$ of the total volume (4.8 gal).

Greenhouse ENVIRONMENT. Plants were grown for 12 weeks inside a $75-\mathrm{m}^{2}$ polycarbonate greenhouse compartment controlled by an environmental control system (Gemlink; Hortimax, Rancho Santa Margarita, CA). Air temperature, RH, and DLI were monitored with temperature and RH probes (HMP60-L; Campbell Scientific, Logan, UT) and quantum sensors (SQ512; Apogee Instruments, Logan, UT), respectively, interfaced to a datalogger (CR1000, Campbell Scientific) and multiplexer (AM16/32B, Campbell Scientific). Replicate hydroponic systems were placed on top of four $15-\times$ 6 -ft metallic benches, each with one temperature/RH probe, and one quantum sensor placed at midcanopy height. All measurements were made every $30 \mathrm{~s}$ and recorded at $60-\mathrm{min}$ intervals. For experimental run 1 in 2018 , the climate readings (mean \pm $\mathrm{SD})$ were $31 \pm 6^{\circ} \mathrm{C}$ day temperature, $22 \pm 2{ }^{\circ} \mathrm{C}$ night temperature, $67 \% \pm$ $8 \% \mathrm{RH}$, and $32.4 \pm 7 \mathrm{~mol} \cdot \mathrm{m}^{-2} \cdot \mathrm{d}^{-1}$ DLI. For experimental run 2 in 2019 , the climate readings were $28 \pm 6{ }^{\circ} \mathrm{C}$ day temperature, $22 \pm 3{ }^{\circ} \mathrm{C}$ night temperature, $68 \% \pm 5 \% \mathrm{RH}$, and $27.7 \pm 6$ $\mathrm{mol} \cdot \mathrm{m}^{-2} \cdot \mathrm{d}^{-1}$ DLI.

INDOOR ENVIRONMENT. Following the same procedures as previously described, on 22 Aug. 2018 and 12 Mar. 2019, one tomato plant was transplanted into each replicate hydroponic system and grown for 12 weeks inside a growth room, set at a constant temperature of $21{ }^{\circ} \mathrm{C}$. Plants were grown under ambient $\mathrm{RH}$ and an average DLI of $20 \pm 2$ $\mathrm{mol} \cdot \mathrm{m}^{-2} \cdot \mathrm{d}^{-1}\left(347 \pm 48 \mu \mathrm{mol} \cdot \mathrm{m}^{-2} \cdot \mathrm{s}^{-1}\right.$; $16-\mathrm{h} \cdot \mathrm{d}^{-1}$ photoperiod from 0600 to $2200 \mathrm{HR}$ ) provided by broadband white LEDs (RAY66 PhysioSpec Indoor, Fluence Bioengineering). A light map was generated to determine the average PPFD at midcanopy height, using a spectroradiometer (SS-110, Apogee Instruments). The light output to achieve the target PPFD was controlled with a dimmer (Solunar, Fluence Bioengineering). To minimize location effects within the experimental area, all hydroponic systems were randomly rotated every 3 d until week 6 , and afterward once per week until the final harvest at week 12. Ambient air temperature was monitored with nine shielded temperature sensors (Elitech, Milpitas, CA) placed strategically around the growth room. Near-canopy air temperature was measured with 10 type-K thermocouples $(0.1 \mathrm{~mm}$ diameter) placed underneath midcanopy leaves of plants located throughout the experimental area. Thermocouples were interfaced to datalogger (CRI000, Campbell Scientific) and a multiplexer (AM16/32B, Campbell Scientific). Measurements were made every $30 \mathrm{~s}$ and recorded at 60-min intervals. For both experimental runs, the mean \pm SD of near-canopy air temperature and $\mathrm{RH}$ were $21 \pm 2{ }^{\circ} \mathrm{C}$ and $60 \% \pm 4 \%$, respectively.

Data Collected. At week 12, final responses to the two nutrient solution management treatments were compared for plants grown in the greenhouse, with four or five replicate hydroponic systems for the $\mathrm{W}$ and $\mathrm{W} / \mathrm{O}$ treatments in experimental run 1 or 2 , respectively. Plants in the $\mathrm{W}$ treatment were also destructively harvested every 2 weeks in both environments. In the greenhouse, there were three (experimental run 1) or four (experimental run 2) replicate hydroponic systems for the $W$ treatment harvested every 2 weeks until week 10 , plus the final four or five final replicates at week 12 in experimental runs 1 and 2, respectively. In total, there were 49 and 9 harvests of the $\mathrm{W}$ and $\mathrm{W} / \mathrm{O}$ treatments, respectively, in the greenhouse over the two experimental runs. For the first and second experimental runs in the indoor environment, five replicate hydroponic systems were destructively harvested every 2 weeks, including the final harvest at week 12. In total, there were 60 harvests indoors over the two experimental runs.

Solution EC and $\mathrm{pH}$ were monitored with an $\mathrm{EC}$ and $\mathrm{pH}$ meter (HI 9813-6N; Hanna Instruments, Carrollton, TX) and recorded every week. The volume of refill water required to maintain reservoir levels above $4.8 \mathrm{gal}$ was recorded every 2 weeks for each replicate hydroponic system. For every harvest, shoots were cut at the base of the stem near the substrate plug. The number of leaves $(>1 \mathrm{~cm})$ per plant was counted, and total leaf area was measured using a leaf area meter (LI-3100C; LI-COR Biosciences, Lincoln, NE). Shoots (stem, leaves, and flowers) were weighed with an electronic balance to obtain shoot fresh weight, and tissue was oven-dried at $70{ }^{\circ} \mathrm{C}$ for $72 \mathrm{~h}$ to determine shoot dry weight. Proportional parts of the cumulative dry tissue (including stems and leaves) were ground to obtain a sample of at least $2 \mathrm{~g}$ used to monitor nutrient uptake. Tissue and nutrient solution samples were analyzed from each destructively sampled replicate hydroponic system to measure essential plant nutrients. Total Kjeldahl $\mathrm{N}$ was measured by semiautomated colorimetry following procedures described by O'Dell (1993), and P, $\mathrm{K}, \mathrm{Ca}, \mathrm{Mg}, \mathrm{S}, \mathrm{Fe}, \mathrm{Mn}, \mathrm{B}, \mathrm{Cu}, \mathrm{Zn}$, and $\mathrm{Na}$ concentrations were measured by inductively coupled plasma atomic emission spectrophotometry (Quality Analytical Laboratories, Panama City, FL). In addition, the number of immature, mature, and BER-affected fruit per plant were counted, and the corresponding fresh weight per plant was recorded immediately after the final harvest at week 12.

Data analysis. Because conditions (i.e., light, temperature, humidity, airflow, among others) within the greenhouse and indoor environments were different, data were subject to separate analyses of variance. However, comparative statements between the different trends are made in the results and discussion section to provide points of reference for each response variable, and to highlight the importance of adjusting recommendations based on environmental plant responses. The experiment was replicated twice over time (2018 and 2019) and had a completely randomized design. Data were pooled between replications over time, as the statistical interactions between treatment and replication were not significant $(P \geq 0.05)$. Treatment comparisons for the final destructive harvest, fruit yield, EC, total refill water, and nutrient uptake of plants grown in the greenhouse were subject to a Student's $t$ test using the fit model procedure of JMP (version 12; SAS Institute, Cary, NC). A regression analysis was conducted to characterize growth over time in both environments (greenhouse or indoors) using SigmaPlot (version 
13.0; Systat Software, San Jose, CA). Linear and quadratic fits were evaluated. Based on the $r$-square value for each model, a linear fit was chosen for all variables in both environments.

\section{Results and discussion}

N U T R I E N T S O L U T I O N MANAGEMENT. Within the greenhouse, solution management treatment did not affect the final leaf number, but plants under $\mathrm{W}$ had $18 \%$ larger leaves, and $12 \%$ and $15 \%$ lower shoot fresh and dry weight, respectively, compared with those in the $\mathrm{W} / \mathrm{O}$ treatment (Fig. 1). In addition, plants grown under $\mathrm{W} / \mathrm{O}$ had more fruit affected by BER and 28\% and $18 \%$ lower mature and total fruit fresh weight, respectively, than those under W (Table 1). However, the number of mature fruit and the total fruit number did not differ between treatments. These trends are consistent with the literature on effects of $\mathrm{EC}$ and $\mathrm{N}$ concentration in hydroponic solutions, which were both higher in the $\mathrm{W} / \mathrm{O}$ treatment.

Adequate EC levels for tomato production can range from 1.6 to 5.0 $\mathrm{dS} \cdot \mathrm{m}^{-1}$ (Dorais et al., 2000), which were within the EC ranges measured every 2 weeks immediately after a nutrient solution replacement in the $\mathrm{W}$ treatment, and throughout the production cycle in $\mathrm{W} / \mathrm{O}$ (Fig. 2). However, EC levels in the higher end of this range can decrease tomato fruit yield and reduce water uptake (Mitchell et al., 1991; Papadopoulos and Rending, 1983) through a reduction in both water potential (Dorais et al., 2000; Reina-Sánchez et al., 2005; Soria and Cuartero, 1997) and leaf area (Alarcon et al., 1994; Heuvelink, 2018) (Table 2). After week 2, EC was consistently higher in the solution of plants grown in the greenhouse under $\mathrm{W} / \mathrm{O}$ compared with $\mathrm{W}$, and the highest solution EC was measured in the $\mathrm{W} / \mathrm{O}$ treatment at week $10\left[4.5 \mathrm{dS} \cdot \mathrm{m}^{-1}(\right.$ Fig. $\left.2 \mathrm{~A})\right]$.

High solution EC lowers tomato fruit yield due to a reduction of water flux into the fruit (Adams, 1991; Adams and Ho, 1989; Adams and Holder, 1992; Buck et al., 2008; Johnson et al., 1992), which primarily affects yield by reducing fruit size rather than fruit number per se (Adams, 1991; Gormley and Maher, 1990; Nakano et al., 2010; Shalhevet and Yaron, 1973; Willumsen et al.,
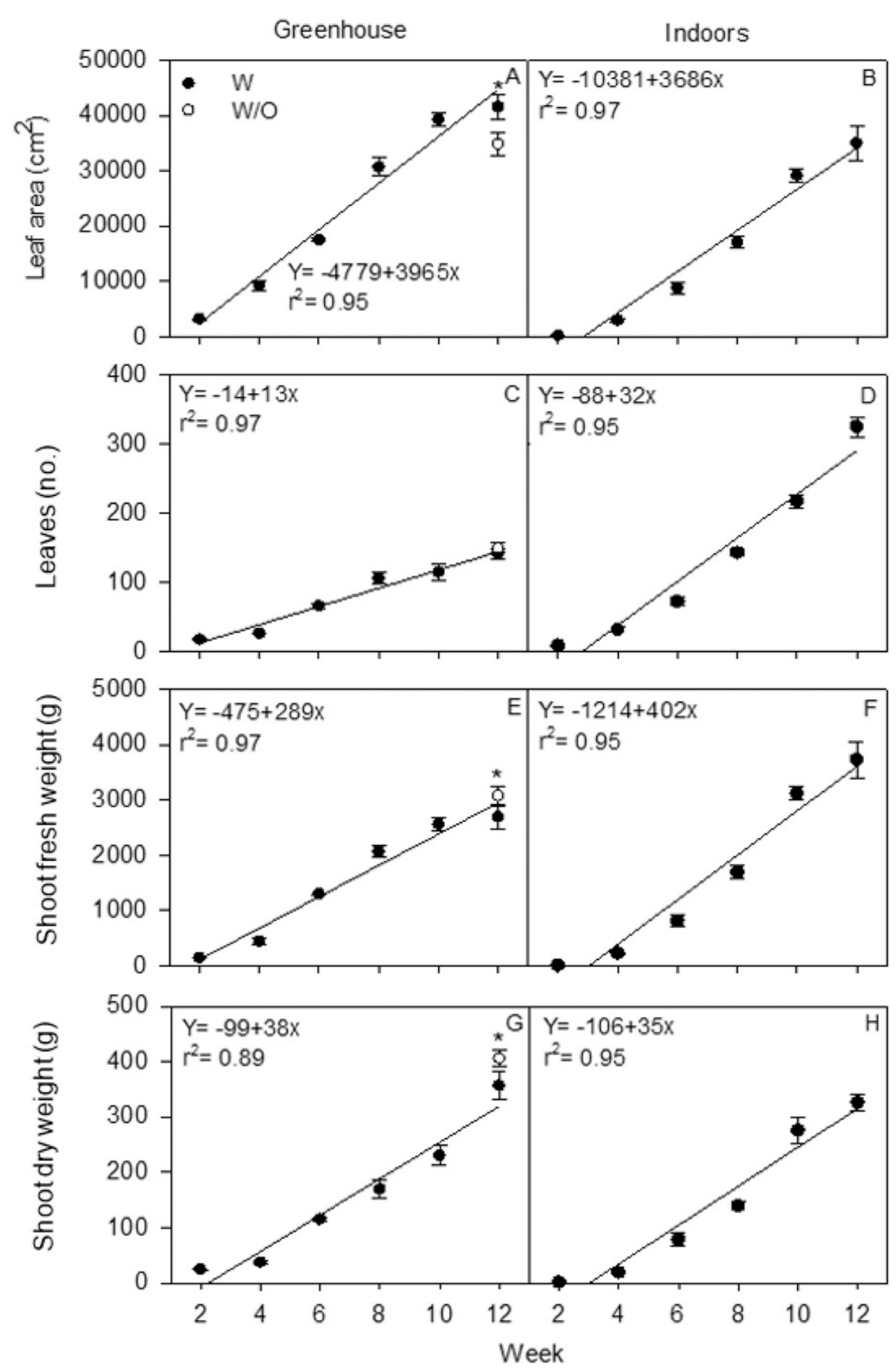

Fig. 1. Growth parameters measured for tomato plants grown inside a greenhouse $(n=8$ to 9$)$ or indoor $(n=10)$ environment for 12 weeks with a nutrient solution replacement every 2 weeks $(\mathrm{W})$, and final growth parameters for plants grown in the greenhouse without $(\mathrm{W} / \mathrm{O})$ a nutrient solution replacement. Data represent average mean \pm SE from one plant per replicate hydroponic system per environment. Asterisks (*) depict significant differences measured at week 12 between the two solution management treatments in the greenhouse according to the Student's $t$ test at $P \leq 0.05 ; 1 \mathrm{~cm}^{2}=0.1550$ inch $^{2}, 1 \mathrm{~g}=0.0353 \mathrm{oz}$.

1996). This corresponds with the results observed in our study for total fruit number and total fruit fresh weight (Table 1). Furthermore, the high incidence of BER measured under $\mathrm{W} / \mathrm{O}$ is another common problem in tomato grown under high solution EC caused by an osmotic reduction of Ca uptake by roots, and an increased resistance to $\mathrm{Ca}$ translocation in the xylem sap (Adams and Holder, 1992; Willumsen et al., 1996). 
Table 1. Final fruit yield measured for tomato plants grown with a nutrient solution replacement every 2 weeks (W) or without a solution replacement for 12 weeks $(\mathrm{W} / \mathrm{O})$ inside a greenhouse or indoor environment. ${ }^{\mathrm{z}}$

\begin{tabular}{|c|c|c|c|}
\hline \multirow[b]{2}{*}{ Yield variable } & \multicolumn{2}{|c|}{ Greenhouse } & \multirow{2}{*}{$\frac{\text { Indoors }}{\mathrm{W} / \mathrm{O}}$} \\
\hline & $\mathbf{W}$ & $\mathrm{W} / \mathrm{O}$ & \\
\hline \multicolumn{4}{|l|}{ Fruit (no.) } \\
\hline Immature & $24 b^{y}$ & $40 \mathrm{a}$ & 33 \\
\hline Mature & $20 \mathrm{a}$ & $17 \mathrm{a}$ & 0 \\
\hline Total & $44 \mathrm{a}$ & $57 \mathrm{a}$ & 33 \\
\hline Blossom-end-rot incidence & $12 \mathrm{~b}$ & 38 a & 0 \\
\hline \multicolumn{4}{|l|}{ Fruit fresh weight $(g)^{x}$} \\
\hline Immature & $1,937 \mathrm{a}$ & $2,041 \mathrm{a}$ & 995 \\
\hline Mature & $3,902 \mathrm{a}$ & $2,804 \mathrm{~b}$ & 0 \\
\hline Total & 5,839 a & $4,845 \mathrm{~b}$ & 995 \\
\hline
\end{tabular}
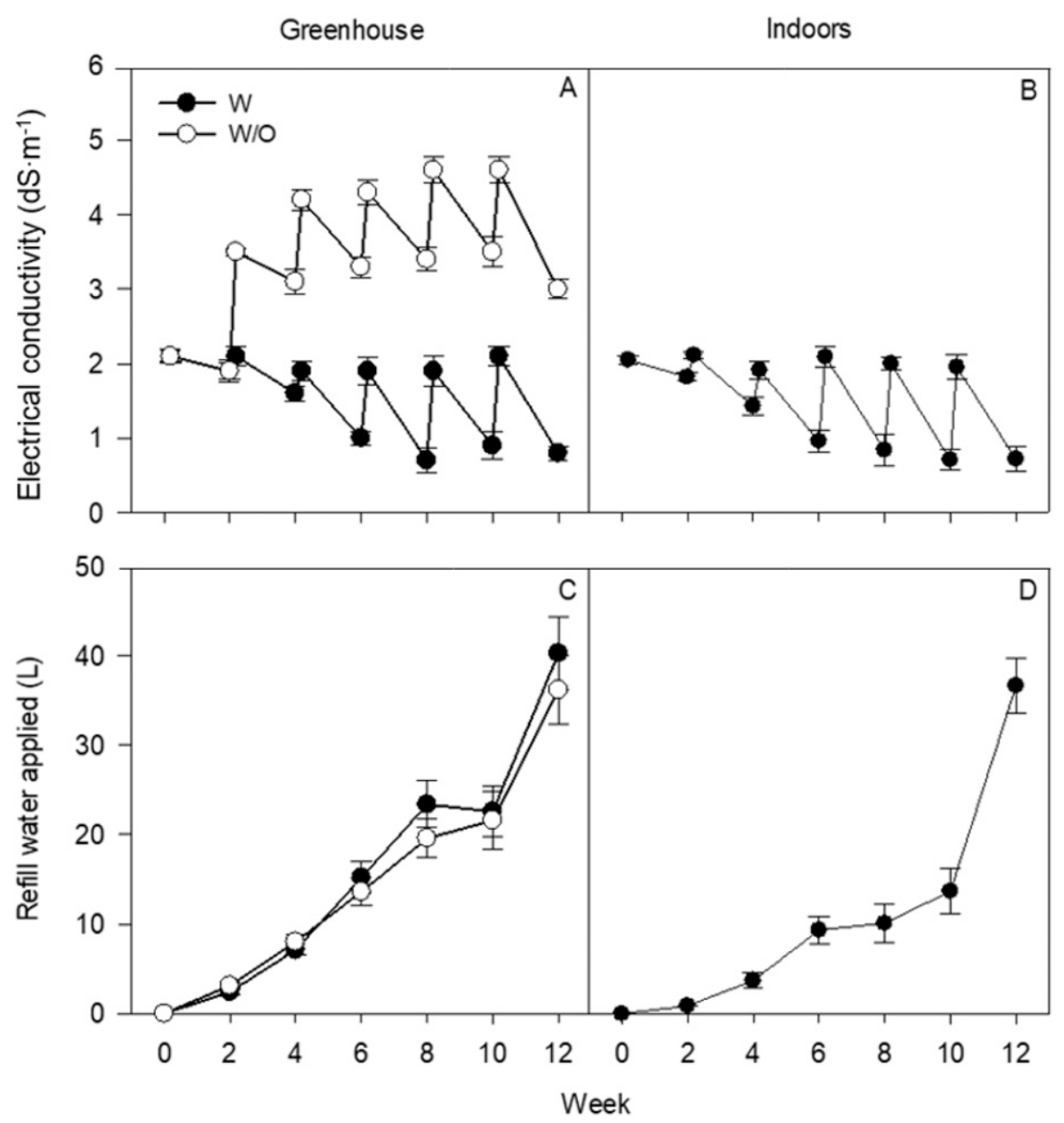

Fig. 2. Electrical conductivity and refill water applied over time for tomato plants grown inside a greenhouse $(n=8$ to 9$)$ or indoor $(n=10)$ environment for 12 weeks with $(\mathrm{W})$ or without $(\mathrm{W} / \mathrm{O})$ a nutrient solution replacement every 2 weeks. Data represent average mean \pm SE from one plant per replicate hydroponic system per environment; $1 \mathrm{dS} \cdot \mathrm{m}^{-1}=1 \mathrm{mmho} / \mathrm{cm}, 1 \mathrm{~L}=0.2642 \mathrm{gal}$.

The total volume of refill water applied was $10 \%$ higher when plants were grown under $\mathrm{W}$ compared with $\mathrm{W} / \mathrm{O}$ in the greenhouse, which probably was the result of a combined effect from plants growing under a lower solution EC and having a greater leaf area under the $\mathrm{W}$ treatment, affecting water potential and transpiration, respectively (Table 2, Fig. 1). It is also likely that the higher water demand from plants grown under $\mathrm{W}$ compared with $\mathrm{W} / \mathrm{O}$, as indicated by the total refill water applied (Fig. 2C), was affected by the higher total fruit fresh weight, which as shown by others, can significantly affect water uptake by tomato plants (Hossain and Nonami, 2011).

The higher shoot fresh and dry weight measured under $\mathrm{W} / \mathrm{O}$ may have resulted from the accumulation of $\mathrm{N}$ in the solution (Table 3 ), because high $\mathrm{N}$ concentration tends to favor partitioning toward vegetative tomato growth (Abdel-Mawgoud et al., 2007; Le Bot et al., 2001; Mercado Luna et al., 2014; Scholberg and Locascio, 1999; Schwarz et al., 2002). In addition, the high temperatures recorded in the greenhouse $\left(>28{ }^{\circ} \mathrm{C}\right)$ could have increased the threshold at which tomato biomass is negatively affected by solution EC (Dalton et al., 1997; Schwarz et al., 2002). Therefore, it is likely that under the environmental conditions used in this study, the high solution EC of plants grown under $\mathrm{W} / \mathrm{O}$ was not limiting enough to affect vegetative biomass production (Charbonneau et al., 1988; Maas and Hoffman, 1977).

Table 3 shows the final nutrient concentration in the solution of plants grown in the greenhouse at week 12 , which resulted from the concentration changes in the last 2 weeks (from week 10 to 12 ) in the $\mathrm{W}$ treatment, or from the combined effect of nutrient depletion, addition of nutrients from tap water, and uptake by plants in the $\mathrm{W} / \mathrm{O}$ treatment. The final concentration of all nutrients was significantly lower in the solution of plants grown under $\mathrm{W}$ compared with $\mathrm{W} / \mathrm{O}$, where $\mathrm{N}, \mathrm{P}$, $\mathrm{K}$, and $\mathrm{Mn}$ were almost completely depleted by week 12. Considering that there was no treatment effect on final tissue nutrient concentration, and that values were generally within survey ranges (Jones, 2008) (Table 4 ), it appears that the nutrient solution strength $\left(178 \mathrm{mg} \cdot \mathrm{L}^{-1} \mathrm{~N}\right)$ and/or the frequency of solution replacement were just sufficient to meet nutrient uptake requirements in the greenhouse under W.

Although a previous study by Solis-Toapanta et al. (2020b) showed that hydroponic basil can be 
successfully grown under $\mathrm{W} / \mathrm{O}$ for 8 weeks with a solution EC as high as $5.5 \mathrm{dS} \cdot \mathrm{m}^{-1}$, results from this study using $\mathrm{W} / \mathrm{O}$ confirmed the findings of others that show a reduction in yield and an increase in BER as a result of a high solution EC when growing tomato plants hydroponically (Table 1, Fig. 2A) (Adams, 1991; Buck et al., 2008; Heuvelink, 2018). The large differences in nutrient demand and susceptibility to high EC between fruiting crops such as tomato, and herbs such as basil, warrant different nutrient solution management strategies that must consider specific crop needs and plant responses to the production environment. Therefore, a general recommendation is not suitable for home gardeners trying to successfully grow fruiting crops and herbs using small-scale hydroponics in residential spaces that can range from indoor rooms, to patios with partial shade, or backyards under full sunlight. Because small-fruit types like cherry tomatoes are considered relatively tolerant to BER caused by moderate water stress (Heuvelink, 2018), they may be potential alternatives for hydroponic home gardeners interested in growing tomato plants

Table 2. Final nutrient solution parameters measured for tomato plants grown with a nutrient solution replacement every 2 weeks $(\mathrm{W})$ or without a solution replacement for 12 weeks $(\mathrm{W} / \mathrm{O})$ inside a greenhouse or indoor environment. ${ }^{\mathrm{z}}$

\begin{tabular}{|c|c|c|c|}
\hline \multirow[b]{2}{*}{ Nutrient solution parameter ${ }^{y}$} & \multicolumn{2}{|c|}{ Greenhouse } & \multirow{2}{*}{$\frac{\text { Indoors }}{\mathrm{W}}$} \\
\hline & W & $\mathrm{W} / \mathrm{O}$ & \\
\hline Frequency of refill water applications & $21.0 \mathrm{a}^{\mathrm{x}}$ & $21.0 \mathrm{a}$ & 14.0 \\
\hline Total refill water applied (L) & $111.3 \mathrm{a}$ & $102.2 \mathrm{~b}$ & 74.4 \\
\hline Final electrical conductivity $\left(\mathrm{d} S \cdot \mathrm{m}^{-1}\right)$ & $0.8 \mathrm{~b}$ & $3.0 \mathrm{a}$ & 0.8 \\
\hline
\end{tabular}

and reducing solution replacement intervals. In addition, high solution EC increases quality parameters such as lycopene, sugar, and total soluble solid concentration of tomato fruit, which could be particularly attractive for consumers aiming to produce nutritious fruit (Heuvelink, 2018; Wu and Kubota, 2008). High EC treatments are also more suitable for small-fruit-type tomatoes, as their yield is less affected by high solution EC than that of cultivars with larger fruit (Buck et al., 2008; Cuartero and Fernández-Munoz, 1999).

Environment. Although not statistically compared, total leaf area was similar between the greenhouse and indoor environments; but indoor-grown plants produced almost twice the leaf number than those grown in the greenhouse and therefore had a lower average individual leaf size (Fig. 1). Shoot dry weight was similar in both environments, but indoor-grown plants had a $39 \%$ higher shoot fresh weight at the end of the experiment, indicating a higher leaf water content. In addition, the

Table 3. Final nutrient concentration of a hydroponic solution used for tomato plants grown with a solution replacement every 2 weeks $(\mathrm{W})$ or without a solution replacement for 12 weeks $(\mathrm{W} / \mathrm{O})$ inside a greenhouse or indoor environment. ${ }^{\mathrm{z}}$

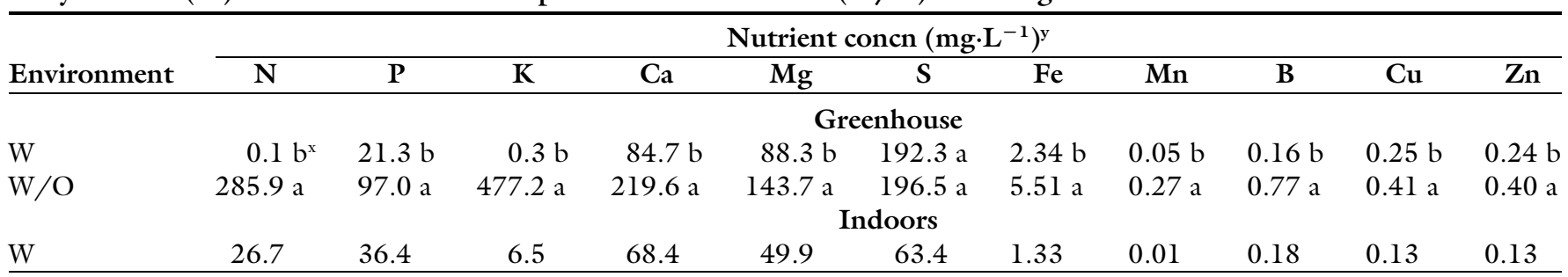

${ }^{\mathrm{z}}$ Values under $\mathrm{W}$ represent nutrients from the solution remaining 2 weeks after a replacement interval at week 10 , whereas those under $\mathrm{W} / \mathrm{O}$ represent the cumulative effect of adding fertilizer to the same solution every 2 weeks up to week 12. Data represent values collected from four replicate hydroponic systems with one plant each within one experimental run $(\mathrm{n}=4)$.

${ }^{\mathrm{y}} \mathrm{l} \mathrm{mg} \cdot \mathrm{L}^{-1}=1 \mathrm{ppm}$.

${ }^{\mathrm{x}}$ For the greenhouse environment, means within column followed by the same letter are not different based on Student's $t$ test at $P \leq 0.05$.

Table 4. Final tissue nutrient concentration for tomato plants grown with a nutrient solution replacement every 2 weeks (W) or without a solution replacement for 12 weeks $(\mathrm{W} / \mathrm{O})$ inside a greenhouse or indoor environment. ${ }^{\mathrm{z}}$

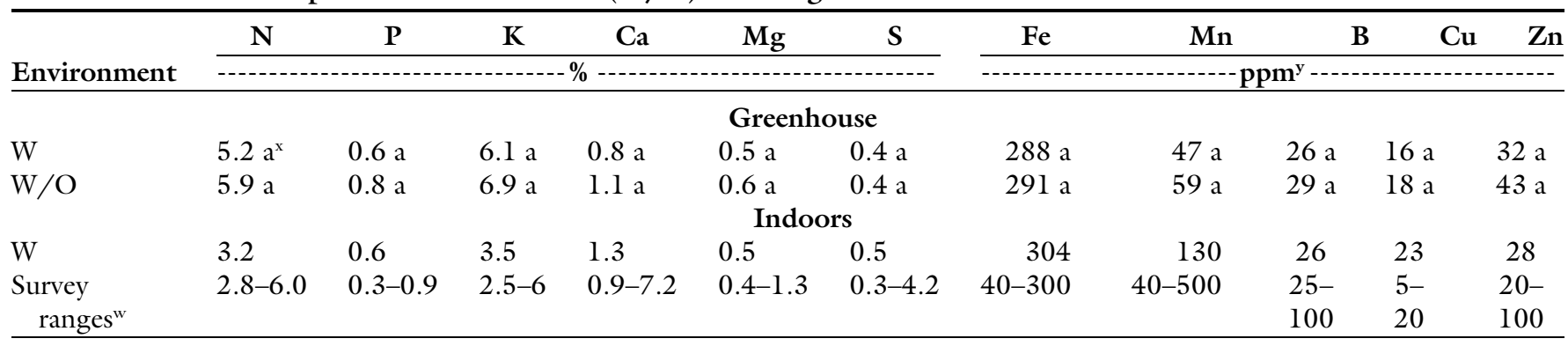

${ }^{\mathrm{z}}$ Data represent average values measured for each replicate hydroponic system with one plant $(\mathrm{n}=9$ to 10$)$ per environment.

${ }^{\mathrm{y}} 1 \mathrm{ppm}=1 \mathrm{mg} \cdot \mathrm{kg}^{-1}$

${ }^{\mathrm{w}}$ Survey ranges from tomato plants during the harvest period (Jones, 2008).

${ }^{\mathrm{x}}$ For the greenhouse environment, means within column followed by the same letter are not different based on Student's $t$ test at $P \leq 0.05$. 
concentration of $\mathrm{N}$ and $\mathrm{K}$ in the tissue was lower in indoor-grown plants compared with those grown in the greenhouse with the same fertilization strategy (W) (Table 4). Plants grown indoors also had a lower yield in terms of total fruit number and fruit fresh weight, and delayed maturity compared with plants grown in the greenhouse (Table 1). More specifically, no mature fruit were harvested from indoor-grown plants, which, coupled with a $49 \%$ to $51 \%$ reduction in immature fruit fresh weight, resulted in a $79 \%$ to $83 \%$ lower total fruit fresh weight compared with those grown in the greenhouse. It is likely that the environmental setpoints used indoors (especially constant air temperature and lower DLI) favored more vegetative growth and less flower production, fruit set, and maturation compared with those used in the greenhouse (Heuvelink, 2018; Nederhoff and Houter, 2009).

Although solution EC over time of indoor-grown plants was similar to that of plants grown under $\mathrm{W}$ in the greenhouse (Fig. 2A and B), the N, P, $\mathrm{K}$, $\mathrm{Ca}$, and $\mathrm{B}$ concentrations were higher in the solution of plants grown indoors compared with those under $\mathrm{W}$ in the greenhouse (Table 3 ), indicating a higher nutrient demand from greenhouse-grown plants. These differences could plausibly explain why BER was not observed in the indoor environment, which is in agreement with the findings of Saure (2001), who noted that low-yielding and slow-growing plants are less affected by BER than those grown in conditions favoring vigorous growth and development.

Growth over time under W followed a linear trend in both environments (Fig. 1), which differed greatly in DLI and temperature, resulting in greater evapotranspiration in the greenhouse as represented by the required refill water (Table 2 ). In addition, greenhouse-grown plants produced 4 to $5 \mathrm{~kg}$ more fruit than those grown indoors, which further increased water and nutrient demand
(Fig. 1, Tables 1 and 3). Accordingly, the refill water volume was about four and a half times the reservoir volume (refill water/6.5-gal reservoir volume) in the greenhouse and three times indoors. Considering that plants grown indoors required less refill water $(8.3 \mathrm{pH})$ than those in the greenhouse, they consistently maintained a lower $\mathrm{pH}$, which made $\mathrm{Fe}$ more available regardless of biweekly $\mathrm{pH}$ adjustments (Fig. 3). Accordingly, our findings show that $\mathrm{Fe}$ uptake was higher indoors than in the greenhouse. Interestingly, Ca uptake was also higher indoors than in the greenhouse, but the opposite trend was measured for $\mathrm{N}, \mathrm{P}, \mathrm{K}$, and $\mathrm{Mg}$. As plants grown indoors only began producing fruit during the last 2 weeks of the experiment, it is likely that at the time of measurement, $\mathrm{Ca}$ had mostly been translocated to leaves, which corresponds with the higher Ca concentration of indoor-grown plants compared with those grown in the greenhouse under W (Table 4), and the yield
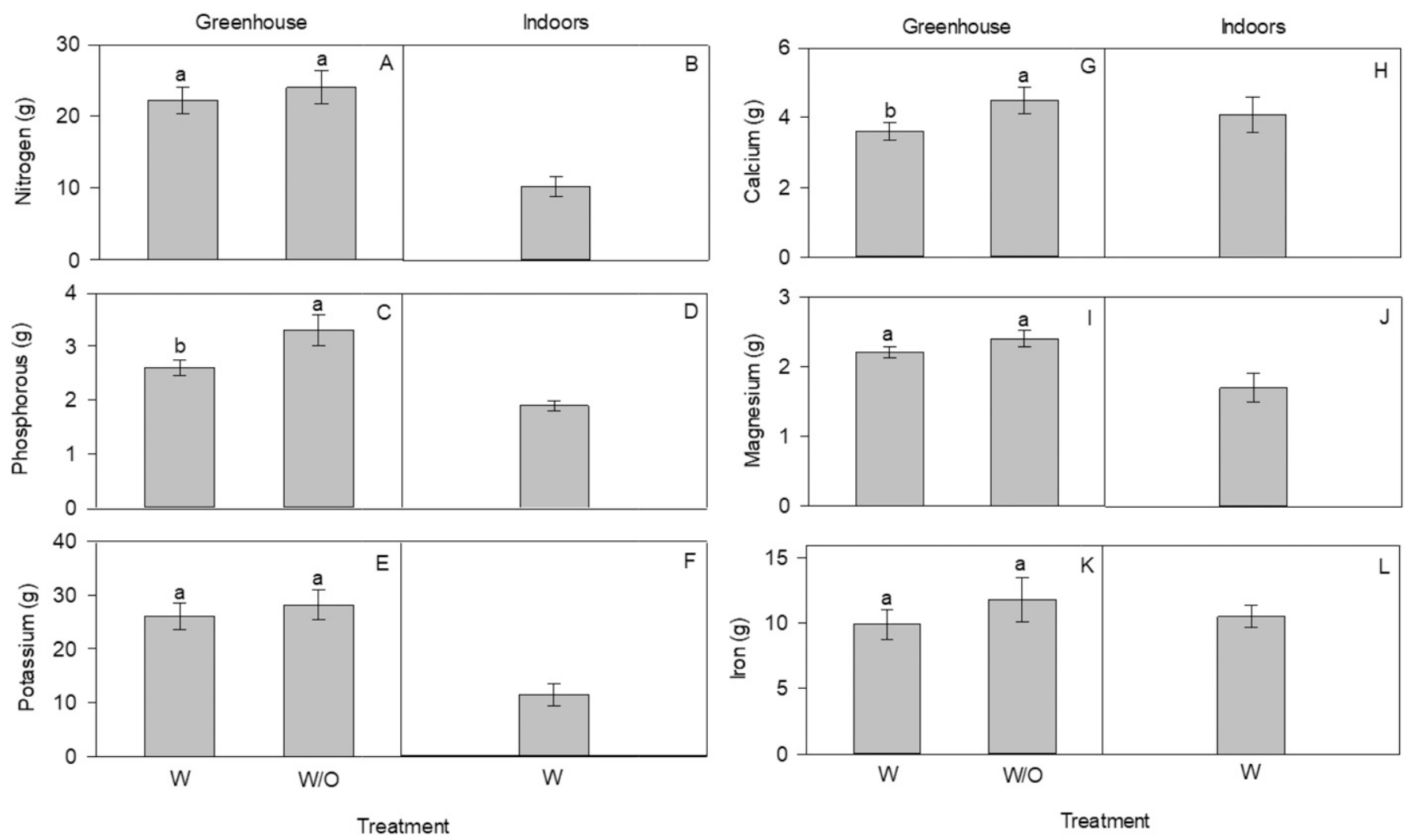

Fig. 3. Nutrient uptake measured for tomato plants grown inside a greenhouse $(n=8$ to 9$)$ or indoor $(n=10)$ environment for 12 weeks with $(\mathrm{W})$ or without $(\mathrm{W} / \mathrm{O})$ a nutrient solution replacement every 2 weeks. Data represent average mean \pm SE from one plant per replicate hydroponic system per environment. For the greenhouse environment, means within a graph with the same letter are not different based on Student's $t$ test at $P \leq 0.05 ; 1 \mathrm{~g}=0.0353 \mathrm{oz}$. 
differences of plants under $\mathrm{W}$ in both environments.

In conclusion, there were advantages and disadvantages from the two solution management treatments compared in this study; and, although the growing environment had only minor effects on shoot growth, it resulted in a large difference in fruit yield and maturity, refill water applied, and frequency of refill water applications. The advantage of $\mathrm{W}$ is that the nutrient solution returned to a balanced concentration and ratio on a regular basis. Although shoot dry weight progressed in a linear fashion over time, there was additional nutrient demand from fruit grown under $\mathrm{W}$, which resulted in the nutrient solution becoming almost completely depleted at the end of the production cycle. An improvement on the $\mathrm{W}$ strategy would be to increase applied fertilizer concentration as fruiting occurs. A disadvantage of using $\mathrm{W}$ is that it would add a waste stream from reservoir replacement that may be polluting for home gardeners. The $\mathrm{W} / \mathrm{O}$ treatment resulted in a higherthan-desired EC and total nutrient concentration by the end of the experiment. Furthermore, compared with the $\mathrm{W}$ treatment, $\mathrm{W} / \mathrm{O}$ resulted in less leaf area, more shoot growth, less water uptake, and similar fruit number-but with higher BER incidence, delayed fruit ripening, and lower fruit fresh weight. Although no major imbalances were measured under $\mathrm{W} / \mathrm{O}$ compared with the initial nutrient solution, the tap water used in our experiment had high chemical water quality. However, in a scenario where the irrigation water source contains high levels of dissolved ions, such as sodium, chloride, or alkalinity, the $\mathrm{W} / \mathrm{O}$ strategy would result in cumulative imbalances over time. As expected, given the higher DLI and temperature, greenhouse-grown plants produced a higher yield than those indoors, but fruit from plants grown indoors were unaffected by BER. Our findings indicate that recommendations for nutrient solution management strategies should consider specific crop needs, growing environments, and production goals by home gardeners. Considering the increasing popularity of small-scale hydroponics, research should continue to evaluate low-input practices that increase resilience and consumer success with hydroponic home gardening of fruiting vegetables.

\section{Literature cited}

Abdel-Mawgoud, A.M.R., N.H.M. ElGreadly, Y.I. Helmy, and S. Singer. 2007. Responses of tomato plants to different rates of humic-based fertilizer and NPK fertilization. J. Appl. Sci. Res. 3:169-174.

Adams, P. 1991. Effects of increasing the salinity of the nutrient solution with major nutrients or sodium chloride on the yield, quality and composition of tomatoes grown in rockwool. J. Hort. Sci. 66:201-207, doi: 10.1080/00221589.1991.11516145.

Adams, P. and L.C. Ho. 1989. Effects of constant and fluctuating salinity on the yield, quality and calcium status of tomatoes. J. Hort. Sci. 64:725-732, doi: $10.1080 / 14620316.1989 .11516015$.

Adams, P. and R. Holder. 1992. Effects of humidity, $\mathrm{Ca}$, and salinity on the accumulation of dry matter and Ca by the leaves and fruit of tomato (Lycopersicon esculentum). HortScience 67:137-142, doi: 10.1080/ 00221589.1992.11516230.

Alarcon, J.J., M.J. Sanchez-Blanco, M.C. Bolarin, and A. Torrecillas. 1994. Growth and osmotic adjustment of two tomato cultivars during and after saline stress. Plant Soil 166:75-82, doi: 10.1007/ BF02185483.

Ambrose, G., K. Das, Y. Fan, and A. Ramaswami. 2020. Is gardening associated with greater happiness of urban residents? A multi-activity, dynamic assessment in the Twin-Cities region, USA. Urban Regional Planning 198:103776, doi: 10.1016/ j.landurbplan.2020.103776.

Buck, J.S., C. Kubota, and M. Jensen. 2008. Effect of mid-day reduction of high electrical conductivity treatment on the yield and quality of greenhouse cherry tomato. HortTechnology 18:460-466, doi: 10.21273/HORTTECH.18.3.460.

Bugbee, B. 2004. Nutrient management in recirculating hydroponic culture. Acta Hort. 648:99-112, doi: 10.17660/ ActaHortic.2004.648.12.

Charbonneau, J., A. Gosselin, and M.J. Trudel. 1988. Influence of electric conductivity and intermittent flow of the nutrient solution on growth and yield of greenhouse tomato in NFT. Soilless Culture 4:19-30, doi: 10.4141/cjps88033.

Christie, E. 2014. Water and nutrient reuse within closed hydroponic systems. MS Thesis, Georgia Southern Univ., Statesboro.

Cuartero, J. and R. Fernández-Munoz. 1999. Tomato and salinity. Scientia Hort.
78:83-125, doi: 10.1016/S0304-4238(98) 00191-5.

Dalton, F.N., A. Maggio, and G. Piccinni. 1997. Effect of root temperature on plant response functions for tomato comparison of static and dynamic salinity stress indices. Plant Soil 192:307-319, doi: 10.1023/A:1004263505595.

Dorais, M., C.A. Mitchell, and C. Kubota. 2017. Lighting greenhouse fruiting vegetables, p. 159-169. In: R. Lopez and E. Runkle (eds.). Light management in controlled environments. Meister, Willoughby, $\mathrm{OH}$.

Dorais, M., R. Dorval, D.A. Demers, D. Micevic, G. Turcotte, X. Hao, A.P. Papadopoulos, D.L. Ehret, and A. Gosselin. 2000. Improving tomato fruit quality by increasing salinity: Effects on ion uptake, growth, and yield. Acta Hort. 511:185-196, doi: 10.17660/ActaHortic. 2000.511.21.

Gormley, T.R. and M.J. Maher. 1990. Tomato fruit quality: An interdisciplinary approach. Progress. Hort. 4:107-112.

Halleck, L.F. 2018. Gardening under lights: The complete guide for indoor growers. Timber Press, Portland, OR.

Heuvelink, E. 2018. Tomatoes: Crop production science in horticulture. CABI, Wallingford, UK.

Hossain, M.M. and H. Nonami. 2011. Fruit growth of tomato associated with water uptake and cell expansion. J. Agr. Technol. 7:1049-1062.

Jacoby, B. 1995. Nutrient uptake by plants, p. 1-22. In: M. Pessarakli (ed.). Handbook of plant and crop physiology. CRC Press, New York, NY.

Johnson, R.W., M.A. Dixon, and D.R. Lee. 1992. Water relations of the tomato during fruit growth. Plant Cell Environ. 15:947-953, doi: 10.1111/j.1365-3040. 1992.tb01027.x.

Jones, J.B. 2008. Tomato plant culture: In the field, greenhouse, and home garden. 2nd ed. CRC Press, Boca Raton, FL.

Kirkpatrick, J.B. and A. Davison. 2018. Home-grown: Gardens, practices and motivations in urban domestic vegetable production. Landsc. Urban Plan. 170:24-33, doi: 10.1016/j.landurbplan.2017.09.023.

Le Bot, J., B. Jeannequin, and R. Fabre. 2001. Impacts of $\mathrm{N}$-deprivation on the yield and nitrogen budget of rockwool grown tomatoes. Agronomie 21:341350, doi: 10.1051/agro:2001128.

Maas, E.V. and G.J. Hoffman. 1977. Crop salt tolerance-Current assessment. 
J. Irrigation Drainage Div., Proc. Amer. Soc. Civ. Eng. 103(IR2):115-134.

Mercado Luna, A., E. Rico García, J.L. Chávez Servín, A. Lara Herrera, and J. Serrano Arellano. 2014. Evaluation of different concentrations of nitrogen for tomato seedling production (Lycopersicon esculentum Mill.). Univ. J. Agr. Res. 2:305-312, doi: 10.13189/ujar.2014. 020804 .

Mitchell, J.P., C. Shennan, S.R. Grattan, and D.M. May. 1991. Tomato fruit yields and quality under water deficit and salinity. J. Amer. Soc. Hort. Sci. 116:215221, doi: 10.21273/JASHS.1 16.2.215.

Nakano, Y., H. Sasaki, A. Nakano, K. Suzuki, and M. Takaichi. 2010. Growth and yield of tomato plants as influenced by nutrient application rates with quantitative control in closed rockwool cultivation. J. Jpn. Soc. Hort. Sci. 79:47-55, doi: 10.2503/jjshs1.79.47.

Nederhoff, E. 1999. Effects of different day/night conductivities on blossom-end rot, quality and production of greenhouse tomatoes. Acta Hort. 481:495-502, doi: 10.17660/ActaHortic.1999.481.58.

Nederhoff, E. and B. Houter. 2009. Plant management for generative or vegetative steering. Practical Hydroponics Greenhouses 84:51-54.

O'Dell, J.W. 1993. Determination of total Kjeldahl nitrogen by semi-automated colorimetry. Environ. Monit. Syst. Lab. $1-15$.
Papadopoulos, I. and V.V. Rending. 1983. Interactive effects of salinity and nitrogen on growth and yield of tomato plants. Plant Soil 73:47-57, doi: 10.1007/BF02197756.

Peet, M.M. 2009. Physiological disorders in tomato fruit development. Acta Hort. 821:151-159, doi: 10.17660/ActaHortic. 2009.821.16.

Reina-Sánchez, A., R. Romero-Aranda, and J. Cuartero. 2005. Plant water uptake and water use efficiency of tomato cultivars irrigated with saline water. Agr. Water Mgt. 2139:1-13, doi: 10.1016/j.agwat. 2005.04.021.

Resh, H.M. 2015. Hydroponics for the home grower. CRC Press, Boca Raton, FL.

Saure, M.C. 2001. Blossom-end rot of tomato (Lycopersicon esculentum Mill.)A calcium- or a stress-related disorder? Scientia Hort. 90:193-208, doi: 10.1016/ S0304-4238(01)00227-8.

Scholberg, J.M.S. and S.J. Locascio. 1999. Growth response of snap bean and tomato as affected by salinity and irrigation method. HortScience 34:259-264, doi: 10.21273/hortsci.34.2.259.

Schwarz, D., H.P. Klaring, M.W. Van Iersel, and I.T. Ingram. 2002. Growth and photosynthetic response of tomato to nutrient solution concentration at two light levels. J.
Amer. Soc. Hort. Sci. 127:984-990, doi: 0.21273/JASHS.127.6.984.

Shalhevet, J. and B. Yaron. 1973. Effect of soil and water salinity on tomato growth. Plant Soil 39:285-292, doi: 10.1007/ BF00014795.

Solis-Toapanta, E., A. Kirilenko, and C. Gómez. 2020a. Indoor gardening with hydroponics: A Reddit community analysis to identify knowledge gaps. HortTechnology 30:346-355, doi: 10.21273/HORTTECH 04574-20.

Solis-Toapanta, E., P. Fisher, and C. Gómez. 2020b. Growth rate and nutrient uptake of basil in small-scale hydroponics. HortScience 55:507-514, doi: 10.21273/ HORTSCI14727-19.

Soria, T. and J. Cuartero. 1997. Tomato fruit yield and water consumption with salty water irrigation. Acta Hort. 458:215-219.

Willumsen, J., K.K. Petersen, and K. Kaack. 1996. Yield and blossom-end rot of tomato as affected by salinity and cation activity ratios in the root zone. J. Hort. Sci. 71:81-98, doi: 10.1080/14620316. 1996.11515385.

Wu, M. and C. Kubota. 2008. Effects of electrical conductivity of hydroponic nutrient solution on leaf gas exchange of five greenhouse tomato cultivars. HortTechnology 18:271-277, doi: 10.21273/ HORTTECH.18.2.271. 